\title{
African American leadership groups: smoking with the enemy
}

\author{
V B Yerger, R E Malone
}

Tobacco Control 2002;11:336-345

See end of article for authors' affiliations

Correspondence to: Valerie Yerger, MA, ND, Center for Tobacco Control Research and Education, 530 Parnassus Avenue, Suite 366, University of California, San Francisco, San Francisco, California, 94143-1390, USA; valyer@itsa.ucsf.edu

Received 5 June 2002 and revision requested 19 September 2002 Accepted 21 September 2002
Background: Among all racial and ethnic groups in the USA, African Americans bear the greatest burden from tobacco related disease. The tobacco industry has been highly influential in the African American community for decades, providing funding and other resources to community leaders and emphasising publicly its support for civil rights causes and groups, while ignoring the negative health effects of its products on those it claims to support. However, the industry's private business reasons for providing such support were unknown.

Objective: To understand how and for what purposes the tobacco industry sought to establish and maintain relationships with African American leaders.

Methods: Review and analysis of over 700 previously secret internal tobacco industry documents available on the internet.

Results: The tobacco industry established relationships with virtually every African American leadership organisation and built longstanding social connections with the community, for three specific business reasons: to increase African American tobacco use, to use African Americans as a frontline force to defend industry policy positions, and to defuse tobacco control efforts.

Conclusion: As the tobacco industry expands its global reach, public health advocates should anticipate similar industry efforts to exploit the vulnerabilities of marginalised groups. The apparent generosity, inclusion, and friendship proffered by the industry extract a price from groups in the health of their members. Helping groups anticipate such efforts, confront industry co-optation, and understand the hidden costs of accepting tobacco industry largesse should be part of worldwide tobacco control efforts.
A frican Americans have struggled for decades to obtain civil rights and combat discrimination. In the process, they forged ties with organisations-including tobacco companies-that offered resources when allies were few. The tobacco industry's longstanding links with African American leaders could be interpreted as representing a laudable commitment to civil rights causes, as the industry claims. However, an alternative interpretation is that these relationships served the industry by helping to keep African Americans engaged as tobacco consumers and silent as opponents. Whatever the intended purposes, the normalised, pervasive presence of tobacco within African American communities has had deadly effects.

Compared to other racial/ethnic groups, African Americans bear the greatest health burden from preventable tobacco related diseases, ${ }^{1-5}$ which kill approximately 45000 African Americans yearly. ${ }^{4}$ Because of this disparity, it is critical to understand how the tobacco industry operates within African American communities, and for what purposes. Although some have suggested that African Americans lack interest in tobacco control, ${ }^{7}$ an increasing number of tobacco control programmes are being implemented by and for black communities. ${ }^{14}$ Some African American leaders have begun speaking out against industry targeting of people of colour. ${ }^{4}$ This paper analyses internal tobacco industry documents to show how deeply embedded ties between African American leadership groups and the industry normalise tobacco use and industry presence, influence African American voices in the tobacco control policy process, and obstruct or weaken tobacco control efforts.

\section{METHODS}

As a result of the 1998 Master Settlement Agreement in the USA, over 40 million pages of internal tobacco industry docu- ments are electronically accessible through tobacco company websites, the University of California, San Francisco's Legacy Tobacco Documents Library, ${ }^{9}$ and others. ${ }^{10-12}$ Documents for this paper were retrieved between February 2001 and April 2002 primarily from the Philip Morris, RJ Reynolds, Brown and Williamson, Lorillard, and Tobacco Institute websites. ${ }^{13-17}$ Additional documents were retrieved from the Minnesota Tobacco Document Depository.

Approximately 700 internal tobacco industry documents pertaining to African American leadership groups were collected and reviewed. Several search strategies were utilised. ${ }^{11}$ We searched for identifiers (for example, "black", "African American"), organisation names (for example, "NAACP"), and names of leaders using a "snowball" approach. Also, we reviewed relevant secondary data sources including newspaper and journal articles. EndNote ${ }^{18}$ software was utilised for data management. Data were analysed to categorise the tobacco industry's practices and goals in establishing influence with African American leaders.

\section{RESULTS}

Background: the tobacco industry and black leadership In the 1930s, about half of all persons employed in manufacturing positions in the tobacco industry were African American. ${ }^{19}$ Philip Morris claims to be the first tobacco

Abbreviations: BEEP, Black Executive Exchange Program; $C B C$, Congressional Black Caucus; CBCF, Congressional Black Caucus Foundation; MBLC, Michigan Black Legislative Caucus; NAACP, National Association for the Advancement of Colored People; NBCSL, National Black Caucus of State Legislators; NUL, National Urban League; PM, Philip Morris; RJR, RJ Reynolds; UNCF, United Negro College Fund 
company to hire black salesmen, ${ }^{20}$ while RJ Reynolds (RJR) was the first in the industry to desegregate its facilities and integrate production lines. ${ }^{419}$ Yet, most blacks were still denied better paying jobs and typically worked in unpleasant conditions. ${ }^{21}$ During the 1940s, however, PM realised that "the black community [made] up a distinct market" 22 and began advertising in black publications. ${ }^{20}$ Other tobacco companies followed. ${ }^{1}$ Henceforth, African Americans were regarded not only as industry labour, but also as potential tobacco consumers. ${ }^{4}$

According to a PM chronology of its corporate involvement in the black community, ${ }^{22}$ tobacco executives George Weissman and Joseph Cullman, both of whom served as PM board chairman and CEO, had established relationships with black organisations by the 1950s. Weissman volunteered with the National Urban League (NUL) and Cullman was an "active supporter of Urban League, NAACP [National Association for the Advancement of Colored People], UNCF [United Negro College Fund], etc." Cullman later joined the NUL board of directors. By the time they became PM's top executives, Weissman and Cullman had been forming ties within the black community for over 30 years.

The industry used its relationships with black organisations to recruit African Americans into its workforce, ${ }^{22}$ which, in turn, intensified tobacco industry presence in black organisations. Many individuals hired by the industry were influential within the African American community. ${ }^{3}$ For example, in the 1940s, PM hired Herb Wright, a former youth director for the NAACP. ${ }^{23}$ Wright worked for PM for 30 years, ${ }^{24}$ expanding PM's reach into black colleges ${ }^{20}$ and black organisations. ${ }^{22}$

Other examples of the intertwined relationships between black leaders and the tobacco industry include Vernon Jordan, former executive director of NUL and former board member of RJR; Margaret Young, widow of former NUL executive director Whitney Young, Jr, and board member of $\mathrm{PM}^{22}$ Ivor $\mathrm{W}$ Hughes, chairman/CEO of Brown and Williamson Tobacco Company and board member of NUL; ${ }^{25}$ Raymond Pritchard, another chairman/CEO of Brown and Williamson, NUL board member, and advisor to Opportunities Industrialisation Centers of America, a black economic development programme; ${ }^{26}$ and Hugh Cullman, PM chairman/CEO and chairman of the board of the United Negro College Fund..$^{27}$ The tobacco industry worked to retain "close, continuing relationships" with virtually every major African American leadership group $^{29}$ (table 1).

\section{Establishing and normalising a tobacco presence}

Black opinion leaders were researched and sought out by the tobacco industry in order to enhance corporate image and improve market position within African American communities. ${ }^{30-32}$ One industry image building strategy was to establish an association with the public service efforts of African American organisations. For example, industry documents describe a PM sponsored symposium focusing on blacks and their civil rights struggle. The 1989 symposium was a collaboration between the Joint Center for Political and Economic Studies (an African American public policy "think tank") and the Smithsonian Institution. To honour Black History Month, eight half-hour programmes were aired on over 200 radio stations in 50 countries. ${ }^{33}$ Each opened and closed with credits for PM. When the estimated three million listeners heard the broadcasts, they also heard the tobacco industry associated with African American accomplishments. RJR likewise associated itself with a highly regarded civil rights organisation by placing its corporate logo on billboards promoting NUL's community service campaigns. ${ }^{34}$

Tobacco money supported African American civil, educational, social, and political organisations and community leaders elected on local, state and federal levels. ${ }^{75}$ (table 1) Support included corporate contributions, business expenses, honoraria, journal ads, and promotional items. ${ }^{36}$ The amount of support was based on the "importance of [the] organisation to [the] company's long term goals". ${ }^{37}$ In 1989, 70\% of PM expenditures to minority organisations went to black groups. ${ }^{36}$

At annual conferences of African American organisations, the tobacco industry built its positive image by displaying to thousands its largesse. For example, the Congressional Black Caucus Foundation's Annual Legislative Weekend attracted up to 50000 of the most influential black leaders in politics, government, business, education, and law. ${ }^{38}$ Tobacco executives socialised and built support by hosting receptions and dinners at these events. ${ }^{39}$

At the 1983 NAACP annual convention, for example, Brown and Williamson announced a "fair share agreement" with the NAACP, promising major economic opportunities for blacks and other minorities.

\section{"These efforts are projected to have a positive result of $\$ 26$ million in purchases from minority vendors in the first fiscal year ... approximately $\$ 4.75$ million to minor- ity advertising and marketing services companies ... approximately 21 percent of the corporate contributions budget [given to organisations which primarily serve minorities]." ${ }^{40}$}

However, a 1984 marketing document elucidates the company's primary motive:

" . . the Fair Share agreement with the NAACP, association with a national civil rights organization can be viewed . . as an endorsement of Brown \& Williamson and its products... if managed with sensitivity, this association can be linked positively to the minority buying public. Clearly, the sole reason for B\&W's interest in the black and Hispanic communities is the actual and potential sales of B\&W products within these communities and the profitability of these sales... this relatively small and often tightly knit [minority] community can work to B\&W's marketing advantage, if exploited properly." ${ }^{41}$ [emphasis added]

The industry extracted something in return from organisations that received its money. For example, when the NAACP relocated an office, RJ Reynolds helped fund the move, but also expected the organisation to facilitate publicity:

\section{"One check is in the amount of $\$ 30,000$ representing our 1987 grant to the NAACP Special Contributions Fund. The second check is in the amount of $\$ 25,000 \ldots$. for the relocation of your office . . it is our understanding that you will provide an appropriate plat- form . . . that we may make public these grants." ${ }^{42}$}

\section{Policy influence}

The tobacco industry expected its relationship with African American political organisations to achieve political and policy goals. ${ }^{43}$ The Congressional Black Caucus Foundation (CBCF), the separate fund raising entity that supports the Congressional Black Caucus's (CBC) political activities, ${ }^{44}$ administers fellowship, internship, and scholarship programmes for aspiring African American leaders. The tobacco industry supported the CBC and CBCF, including at least $\$ 125000$ in $1985,{ }^{45}$ $\$ 50000$ in $1986,{ }^{46}$ and $\$ 155000$ in $1993 .{ }^{47}$ Involvement in these programmes provided opportunities for the industry to link with individuals deemed likely to become future policy leaders and eventual allies, as suggested by a 1990 PM memo: "Purpose of [sponsoring] internships: develop an early 
Table 1 African American organisations with tobacco industry involvement

\begin{tabular}{|c|c|c|c|c|c|c|c|c|c|c|}
\hline \multirow{2}{*}{$\begin{array}{l}\text { Organisation } \\
\text { type* }\end{array}$} & \multirow[b]{2}{*}{ Organisation name } & \multicolumn{4}{|c|}{$\begin{array}{l}\text { Type(s) of tobacco } \\
\text { industry } \\
\text { involvement† }\end{array}$} & \multicolumn{5}{|c|}{ Involved tobacco company(ies) $\ddagger$} \\
\hline & & $\mathrm{C}$ & $\mathrm{E}$ & M & $P$ & BW & LO & PM & RJR & $\mathrm{TI}$ \\
\hline \multirow{35}{*}{$\begin{array}{l}\text { Business/ } \\
\text { professional/ } \\
\text { trade }\end{array}$} & A. Philip Randolph Foundation & & $x$ & & $x$ & $x$ & $x$ & $x$ & $x$ & $x$ \\
\hline & Association of Minority Enterprises of New York & & $x$ & $X$ & $x$ & & & $x$ & & \\
\hline & Black Expo & & $x$ & $x$ & $x$ & & $x$ & $x$ & $x$ & \\
\hline & Black Women in Publishing & & $x$ & $x$ & & & & $x$ & & \\
\hline & Coalition of Black Trade Unionists & $x$ & $x$ & $X$ & $x$ & & & $x$ & & \\
\hline & Conference of Negro Business and Professional Women & & $x$ & & & & & $x$ & & \\
\hline & Dallas Black Chamber of Commerce & & $\mathrm{X}$ & & $x$ & & & $\mathrm{X}$ & & \\
\hline & International Association of Black Professional Fire Fighters & & $x$ & & & & & $x$ & & \\
\hline & National Association of Black \& Minority Chambers of Commerce & & & & $x$ & & & $x$ & & \\
\hline & National Association of Black Journalists & & $x$ & & $x$ & & & $x$ & $x$ & \\
\hline & National Association of Black Social Workers & & $x$ & $x$ & & & & $x$ & & \\
\hline & National Association of Market Developers & $x$ & $x$ & & $x$ & & & $x$ & & \\
\hline & National Association of Minority Contractors & & & & $x$ & & & $\mathrm{X}$ & & $x$ \\
\hline & National Association of Minority Women in Business & & $x$ & & $x$ & & & $x$ & & \\
\hline & National Association for Real Estate Brokers & & $x$ & $x$ & $x$ & & & $x$ & $x$ & \\
\hline & National Association of Women Business Owners & & & $x$ & & & & $x$ & & \\
\hline & National Bankers Association & & $x$ & $x$ & & & & & $x$ & \\
\hline & National Bar Association & & $x$ & $x$ & $x$ & $x$ & & $x$ & $x$ & \\
\hline & National Black Chamber of Commerce & & $\mathrm{X}$ & $x$ & & & & $x$ & $x$ & \\
\hline & National Black MBA's Association & & & $x$ & & & & $x$ & & \\
\hline & National Black Media Coalition & $x$ & $x$ & & & & & $x$ & & \\
\hline & National Black Police Association & & $x$ & & $x$ & & & $x$ & $x$ & $x$ \\
\hline & National Business League & & $x$ & $x$ & $x$ & $\mathrm{X}$ & & $x$ & $x$ & \\
\hline & National Conference of Black Lawyers & & $x$ & & $x$ & & & $x$ & & \\
\hline & National Dental Association & & & $x$ & & $x$ & & & & \\
\hline & National Forum for Black Public Administrators & $x$ & $x$ & $x$ & & & & $x$ & $x$ & $x$ \\
\hline & National Minority Business Council & $x$ & & $x$ & $x$ & & & $x$ & & $x$ \\
\hline & National Minority Supplier Development Council & & $x$ & $x$ & $x$ & $x$ & & $x$ & $x$ & $x$ \\
\hline & National Newspaper Publishers Association & $x$ & $x$ & $x$ & $x$ & $x$ & & $x$ & $x$ & \\
\hline & National Organization of Black Law Enforcement Executives & & $x$ & $x$ & $x$ & & & $x$ & & \\
\hline & National United Affiliated Beverage Association & & $x$ & $x$ & $x$ & & & $x$ & $x$ & \\
\hline & North Carolina Association of Minority Business & & $x$ & $\mathrm{x}$ & & & & $x$ & & \\
\hline & Opportunities Industrialization Centers of America & $x$ & $x$ & $X$ & $x$ & $X$ & & $x$ & $x$ & $x$ \\
\hline & West Coast Black Publishers Association & & $x$ & & $x$ & & & $x$ & & $x$ \\
\hline & World Institute of Black Communications, Inc. & & & $x$ & $x$ & & & $x$ & & \\
\hline \multirow{8}{*}{$\begin{array}{l}\text { Civil/equal } \\
\text { rights }\end{array}$} & American Association for Affirmative Action & & $x$ & & $x$ & & & $x$ & & $x$ \\
\hline & Leadership Conference on Civil Rights & & & & $x$ & & & $x$ & & $x$ \\
\hline & National Association for the Advancement of Colored People (NAACP) & $x$ & $x$ & $x$ & $x$ & $\mathrm{X}$ & $x$ & $x$ & $x$ & $x$ \\
\hline & National Council of Negro Women & $x$ & $x$ & $x$ & & $x$ & & $x$ & $x$ & \\
\hline & National Urban League, Inc (NUL) and local chapters & $x$ & $x$ & $x$ & $x$ & $x$ & & $x$ & $x$ & $x$ \\
\hline & Operation PUSH (Rainbow/PUSH Coalition) & & & $x$ & $x$ & $X$ & & $x$ & $x$ & $x$ \\
\hline & Southern Christian Leadership Conference & & $x$ & $x$ & $x$ & & $\mathrm{X}$ & $x$ & & \\
\hline & United Black Church Appeal & & $x$ & & & & & $x$ & & \\
\hline \multirow{4}{*}{$\begin{array}{l}\text { Community } \\
\text { development }\end{array}$} & 100 Black Men of America & & $x$ & & & & & $x$ & $x$ & \\
\hline & Associated Black Charities & & $x$ & & & & & $x$ & & \\
\hline & National Association of Negro Business and Professional Women's Clubs & & $x$ & $x$ & $x$ & $x$ & & $x$ & $x$ & \\
\hline & National Coalition of 100 Black Women & & $x$ & & $x$ & & & $x$ & & $x$ \\
\hline Educational & Florida A\&M University & & $x$ & & & & & & $x$ & \\
\hline & Jackie Robinson Foundation & $\mathrm{x}$ & $\mathrm{X}$ & & & $x$ & & $x$ & & \\
\hline & Meharry Medical College & $\mathrm{X}$ & $x$ & & & & & $x$ & & \\
\hline & National Association for Equal Opportunity in Higher Education & & $x$ & $x$ & & & & & $x$ & \\
\hline & National Black Child Development Institute, Inc. & & $x$ & & & & & & & $x$ \\
\hline & North Carolina A\&T State University & & $x$ & & & & & & $x$ & \\
\hline & North Carolina Central University & & $x$ & & & & & & $x$ & \\
\hline & Tuskegee Airmen & & $x$ & $x$ & & & & $x$ & & \\
\hline & United Negro College Fund & $x$ & $x$ & & & $x$ & & $x$ & $x$ & \\
\hline & Winston-Salem State University & & $x$ & & & & & & $x$ & \\
\hline Fraternities / & Alpha Kappa Alpha & & $x$ & $x$ & & $x$ & & $x$ & $x$ & \\
\hline sororities & Alpha Phi Alpha & & $x$ & $x$ & & $x$ & & & $x$ & \\
\hline & Delta Sigma Theta & & $x$ & $\mathrm{X}$ & $x$ & $x$ & & $x$ & $x$ & \\
\hline & Kappa Alpha Psi & & $\mathrm{X}$ & $\mathrm{X}$ & & $\mathrm{X}$ & & $\mathrm{X}$ & $x$ & \\
\hline & Omega Psi Phi & & & $x$ & & & & $x$ & & \\
\hline & Phi Beta Sigma & & $x$ & & & & & & $x$ & \\
\hline Political and/or & Black Elected Democrats of Ohio (Ohio Legislative Black Caucus) & & & $x$ & & & & & $x$ & \\
\hline public policy & Congressional Black Caucus & $x$ & $x$ & $x$ & $x$ & $x$ & $x$ & $x$ & $x$ & $x$ \\
\hline & Congressional Black Caucus Foundation & & $\mathrm{X}$ & $\mathrm{X}$ & & $\mathrm{X}$ & $x$ & $\mathrm{x}$ & $x$ & \\
\hline & Georgia Association of Black Elected Officials & & $x$ & $x$ & $x$ & & & $x$ & & $x$ \\
\hline & Georgia Legislative Black Caucus & & $x$ & $x$ & $x$ & & & $x$ & & \\
\hline & Joint Center for Political and Economic Studies & & $x$ & $x$ & & & & $x$ & $x$ & \\
\hline & Louisiana Legislative Black Caucus & & $x$ & & & & & & $x$ & \\
\hline & Massachusetts Legislative Black Caucus & & $x$ & & $x$ & & & $x$ & & \\
\hline
\end{tabular}


Table 1 continued

\begin{tabular}{|c|c|c|c|c|c|c|c|c|c|c|}
\hline \multirow{2}{*}{$\begin{array}{l}\text { Organisation } \\
\text { type* }\end{array}$} & \multirow[b]{2}{*}{ Organisation name } & \multicolumn{4}{|c|}{$\begin{array}{l}\text { Type(s) of tobacco } \\
\text { industry } \\
\text { involvement† }\end{array}$} & \multicolumn{5}{|c|}{ Involved tobacco company(ies) $\ddagger$} \\
\hline & & c & $\mathrm{E}$ & M & $P$ & BW & LO & PM & RJR & TI \\
\hline \multirow{11}{*}{$\begin{array}{l}\text { Regional and/or } \\
\text { public policy } \\
\text { (continued) }\end{array}$} & Michigan Black Legislative Caucus & & $\mathrm{x}$ & & $x$ & & $\mathrm{x}$ & $\mathrm{x}$ & & \\
\hline & National Association of Black County Officials & $\mathrm{x}$ & $x$ & & $x$ & & $\mathrm{x}$ & & $\mathrm{x}$ & \\
\hline & National Black Caucus of State Legislators & & $\mathrm{x}$ & $\mathrm{x}$ & $\mathrm{x}$ & & $\mathrm{x}$ & $\mathrm{x}$ & $\mathrm{x}$ & \\
\hline & National Black Republican Council & & $\mathrm{x}$ & & & & $\mathrm{x}$ & & & \\
\hline & National Conference of Black Mayors & & & $\mathrm{x}$ & $\mathrm{x}$ & & $\mathrm{x}$ & $\mathrm{x}$ & $\mathrm{x}$ & \\
\hline & National Political Congress of Black Women & & & $x$ & & & $\mathrm{x}$ & & & \\
\hline & New York State Black, Puerto Rican, and Hispanic Legislative Caucus & & $\mathrm{x}$ & $\mathrm{x}$ & $\mathrm{x}$ & & $\mathrm{x}$ & & $\mathrm{x}$ & \\
\hline & North Carolina Legislative Black Caucus & & $\mathrm{x}$ & & & & & $\mathrm{x}$ & & \\
\hline & South Carolina Legislative Black Caucus & & $\mathrm{x}$ & & & & $\mathrm{x}$ & & & \\
\hline & Tennessee Caucus of Black State Legislators & & $\mathrm{x}$ & & $\mathrm{x}$ & & $\mathrm{x}$ & $\mathrm{x}$ & & \\
\hline & World Conference of Mayors & & $\mathrm{x}$ & $\mathrm{x}$ & $x$ & & $\mathrm{x}$ & $\mathrm{x}$ & $\mathrm{x}$ & \\
\hline
\end{tabular}

*Categorised according to the National Directory of African American Organizations, located on Philip Morris website.

†C, Corporate/organisational links: documents provide evidence of shared leadership between community organisation and one or more tobacco companies (for example, dual board relationships). E, Economic support: documents provide evidence that one or more tobacco companies or the Tobacco Institute provided economic support for the organisation or its designees. This support may include direct contributions, sponsorships of activities or internships, or covering of other expenses such as travel or office relocation. M, Marketing access: documents provide evidence that the organisation facilitated marketing access to its members for one or more tobacco companies (for example, cigarette sampling allowed at organisation's

functions/events). P, Political exchange: documents provide evidence that one or more tobacco companies or the Tobacco Institute has assisted the organisation in political matters (for example, handled press conferences, press releases, assisted with lobbying, linked organisation with allies), or that the organisation has assisted the tobacco industry in its political matters.

‡BW, Brown and Williamson Tobacco Company; LO, Lorillard Tobacco Company; PM, Philip Morris; RJR, RJ Reynolds; TI, The Tobacco Institute.

relationship with individuals who are likely to wind up in the pub[1]ic policy arena." ${ }^{\prime 8}$ The industry also funded internship and scholarship programmes of other important African American organisations, including the National Newspaper Publishers Association. ${ }^{49} 50$

The industry also sponsored mentoring programmes in order to reach future African American policymakers. For example, RJR participated in the NUL's Black Executive Exchange Program (BEEP). ${ }^{37}$ Established in 1969, BEEP works with black colleges to connect students with African American executives from industry and government. A 1990 report from an RJR employee suggests that industry policy positions were promoted through BEEP seminars:

\section{"The importance of this seminar went beyond the lectures and symposia ... [the] influence that representatives from RJR have on the attendees of the seminar should be noted. It was during conversations with small groups and individuals that this influence was most effective. These conversations provided opportunities to present the smoker's rights position to persons intimately involved in smoking/non-smoking policy-making activities within their companies...."151}

The industry sought generally to establish relationships with politicians early in their careers. ${ }^{52}$ By showering with attention junior and local politicians who were likely to move on to state and federal offices, the industry sought to enlarge its pool of political allies. A 1991 memo written by an RJR representative working in Ohio illustrates the industry's watchful interest in local African American politicians:

"Barbara [Boyd] . . .Vice-Mayor of Cleveland Heights, Ohio . . first-ever black elected official . . .co-founder of the Black Women's Political Caucus, President of the Cleveland Heights Democrats, and the Secretary of the Cuyahoga County Democratic Party . . . Barbara is, without a doubt, going places."

"[Cleveland Mayor Mike White:] . . African-American big city mayor . . . in the process of consolidating his political power . . .it's clear that Mike White can either open or close a number of doors for us. ${ }^{\text {"53 }}$

Industry generosity was undertaken not merely for goodwill's sake, but because it was a way to ensure support for the industry's policy positions. A 1991 RJR memo provides an example of a political organisation offering to support and defend the industry in exchange for tobacco money. When RJR hosted a dinner reception in honour of the Michigan Black Legislative Caucus (MBLC), members of the caucus asked RJR to contribute to a black owned hospital and Detroit youth organisations.

"[We, RJR] . . .were assured that our support would be welcomed, regardless of the probable criticism of anti-smoking activists. We were further assured that $[M B L C]$ would in turn support us . . Caucus members assured us that they were willing to be friends of the industry, and pledged their support." 54

Many other African American organisations that accepted tobacco money have supported the industry by opposing tobacco control legislation. ${ }^{46}{ }^{55}$ For example, during the second half of the 1980s, the federal government was looking for ways to address its budget deficit. Increasing the federal excise tax on tobacco products was one option. Increasing excise taxes is also an effective way to reduce tobacco use, ${ }^{5657}$ especially among African Americans. ${ }^{58}$ It has also been demonstrated that higher excise taxes on tobacco products discourage initiation of smoking, particularly among low income youth. ${ }^{59}$ A 1987 PM marketing memo reveals the industry's knowledge of what an excise tax increase could do:

"You may recall ... that the 1982-83 round of price increases caused two million adults to quit smoking and prevented 600,000 teenagers from starting to smoke. Those teenagers are now 18-21 years old, and since about 70 percent of 18-21 year-olds and 35 percent of older smokers smoke a PM brand, this means that 700,000 of those adult quitters had been PM smokers and 420,000 of the non-smokers would have been PM 
smokers . . . [we] don't need to have that happen again. ${ }^{160}$ [emphasis in original]

Although this memo does not address African American smokers specifically, it suggests why the Tobacco Institute had declared in 1984 that preventing any excise tax increase was the industry's highest priority. ${ }^{61}$

One of the industry's key strategies for fighting tax increases was to argue that excise taxes were regressive and disproportionately unfair, particularly to minorities. ${ }^{62}{ }^{63}$ Displaying credible support for this argument led to an intensified effort to pull minority organisations on board. ${ }^{61}$ In 1981 the Congressional Black Caucus had proposed an alternative to President Reagan's federal budget. ${ }^{64}$ Although the $\mathrm{CBC}$ budget included a tax cut for middle income Americans, ${ }^{65}$ it also contained a $10 \%$ increase in the tobacco excise tax. ${ }^{667}$ This alternative budget would have restored most of the funding for social programmes considered vital to the poor, which were proposed for cuts under the Reagan plan. ${ }^{68}$ Yet, in 1984, for undetermined reasons, the CBC's alternative budget opposed increasing tobacco excise taxes.

The tobacco industry sought to leverage the caucus' changed position, as a 1984 document shows:

\section{"The recent (3/30/84) adoption by the Congressional Black Caucus of an alternative budget program which expressly opposes any increase in or extension of ciga- rette excise taxes. . can be used to industry advantage . . ."169}

By June 1985, the industry felt confident that the National Black Caucus of State Legislators (NBCSL) also opposed increasing excise taxes $^{70}$ and therefore would support the industry's position. According to a Tobacco Institute memo, the industry secured further support from other African American organisations:

"Philip Morris staff has reported that the following groups have or will submit statements in support of our position [on the excise tax]: NAACP, National Urban League, National Association of Black County Officials, National Coalition of 100 Black Women, National Black Police Association...West Coast Black Publishers Association . . and the Georgia Association of Black Elected Officials." ${ }^{.71}$

As part of the industry wide effort, PM distributed to 50 major African American newspapers an op-ed piece apparently authored by James Hargrove, chair of the National Black Police Association, ${ }^{72} 73$ addressing "the inherent unfairness of excise taxes to minorities". ${ }^{2}$ Mr Hargrove, a recipient of tobacco money, ${ }^{72}$ often defended pro-tobacco issues. ${ }^{75-78}$

By the end of 1985, Reverend Jesse Jackson, chair of the National Rainbow Coalition, was also attacking excise taxes. ${ }^{79}$ Citing a 1981 economic study, Jackson asserted that "the tobacco tax burden is as much as 10 times greater for Black consumers". It is unclear whether Jackson understood that the study's author, economist V Glenn Chappell, was research director of the Tobacco Tax Council and consultant to the Tobacco Institute and had been affiliated with the industry since at least $1973 .^{80-82}$

When Congress announced 1987 public hearings on federal revenue options, the tobacco industry solicited additional support from the National Conference of Black Mayors ${ }^{83}{ }^{84}$ and Opportunities Industrialization Centers of America. ${ }^{84}$ The CBC established a task force to review the impact of excise taxes on the poor, blacks, and other minorities, which issued a 1987 report. ${ }^{85}$ Congressman Mervyn Dymally (Democrat, California), chair of the CBC and a recipient of tobacco money, ${ }^{86-89}$ presented the report to congressional committees. Echoing industry positions, Dymally argued that federal excise taxes were unfair, regressive, and disproportionately affected low income families, blacks, and other minorities. ${ }^{90}$ Several memos written by Samuel Chilcote, Tobacco Institute president, reveal that the industry took credit for shaping these views:

"Since January [1987] substantial progress has been made in convincing . . the Congressional Black Caucus . . that excise tax increases would hurt the poor . . ."191

The tobacco industry coordinated press conferences and media placements of op-eds to promote Dymally's task force report.
"[Dymally] will conduct a press conference next week to release his report on excise tax regressivity... [The Tobacco Institute] is coordinating the press event and coverage ..." ${ }^{192}$
"By the end of December [1987], twenty black publica- tions had published op-eds prepared by . . . Dymally opposing increased federal excise taxes. We [the Tobacco Institute] coordinated the project . . ."

In 1989, the threat of increased excise taxes still existed on Capitol Hill. The tobacco industry maintained its connection with Dymally (who once publicly admitted to voting on behalf of tobacco even when it conflicted with his own views ${ }^{94}$ ) as a resource to help the industry and its allies kill tax proposals.95 Industry spokespersons continued quoting Dymally into at least the early 1990s, ${ }^{96-98}$ even after he was no longer a member of Congress.

Representative Charles Rangel from New York, another CBC member, has taken tobacco money. ${ }^{869-101}$ Despite previously supporting legislation to inform the public of tobacco's dangers (H.R. 4957) and legislation acknowledging that smoking increased cancer mortality for blacks (H.R. 4856), ${ }^{102}$ Rangel was a congressional contact for the industry ${ }^{103}$ and thought to be "willing to compromise with the tobacco industry". ${ }^{104}$ On the state level, powerful politician Willie Brown, former speaker of the California House and current mayor of San Francisco, was a longtime recipient of tobacco industry contributions who repeatedly used his power to thwart tobacco control measures. ${ }^{105}$

The industry also drew on ties with African American leaders to circumvent local tobacco control policies and exploit promotional opportunities. For example, a 1984 RJR sports sponsorship promotional plan for Chicago noted that:

" . . almost all softball league games are played on Park District or Chicago Board of Education grounds. RJRT's own policies prohibit sampling on school grounds. In addition ... .Chicago Park District regulations prohibit the sampling of cigarettes on Park District grounds. However, our contacts to [sic] various political representatives . . .lead us to believe we could receive some support/assistance from local black politicians in obtaining permission to sample at these activities." 106

The tobacco industry's presence was not always evident. It often called upon third party "allies" within minority groups to approach black leaders on its behalf. ${ }^{107}$ For example, the industry urged the West Coast Black Publishers and the Black Professional Fire Fighters to write to CBC members, asking them to oppose tobacco control legislation ${ }^{108}$ and co-sponsor pro-tobacco legislation. ${ }^{109}$ When the Tobacco Institute planned to contact the Council of Black Churches for assistance in distributing the industry's booklet "Tobacco: Helping Youth Say $\mathrm{No}^{\prime \prime}$, Benjamin Ruffin, RJR's African American vice president 
of corporate affairs, warned the Institute that "tobacco people might not be enthusiastically received" by the council. ${ }^{110}$ Heeding Ruffin's warning, the Tobacco Institute called upon Norm Hill of the A Philip Randolph Foundation, a black trade union organisation named after the civil rights leader, to meet with the church council. The foundation, also a recipient of tobacco money, ${ }^{111}$ had previously supported the industry's efforts in opposing excise tax increases. ${ }^{93}$

\section{Emerging African American resistance}

African Americans were not, however, merely passive recipients and industry pawns. Some questioned and challenged industry practices. For example, in 1984 a beneficiary of an industry supported internship programme questioned the distribution of cigarette samples, a common practice at many African American events. ${ }^{112-117}$ CBCF intern Mark Mitchell, MD, MPH, wrote to CBCF executive director Frank Morris expressing concern that smoking was especially harmful to blacks and requesting that the CBCF policy board reconsider the practice of allowing cigarette distribution at its events.

"I am very much disturbed by the [CBCF's] policy of promoting cigarette smoking. . .I am requesting that you raise these issues . . . in the hope that we will adopt a policy more in line with . . the well-being of Black Americans . . Cigarette promotions have been highly successful in coercing Black people to begin smoking . . . Yet CBCF has not discouraged smoking. On the contrary[,] it is encouraging more Blacks to smoke."

It is unclear whether the CBCF board saw the Mitchell letter, but executive director Morris forwarded a copy to Norm Gaines, the RJR representative who supplied cigarettes for the CBCF events, ${ }^{119}$ noting:

"One of our scholars . . contends that there is evidence to show that heavy cigarette smoking by Black Americans [note: nowhere in Dr Mitchell's memo is there a reference to "heavy cigarette smoking"] is having a disproportionately negative impact on the health of Black Americans ... We want to hear all sides of this issue and to see whether you or the Tobacco Institute has any information on the impact of cigarette smoking upon Black Americans." ${ }^{120}$

We were unable to locate a reply from Gaines, but an unsigned letter in the Tobacco Institute collection dated August 1984 appears to be a prepared response to Morris's request. Although the industry had known since the 1950s that smoking is associated with cancer, ${ }^{121}$ the letter asserts:

"To draw a conclusion that smoking causes certain chronic diseases and other adverse health conditions in blacks . . . is not justified in our view. ${ }^{122}$

Despite Dr Mitchell's attempt to intervene, tobacco presence continued at CBCF events. In 1987, three years after Dr Mitchell's letter, CBC members Julian Dixon and Mickey Leland asked PM for \$75 000 and a three year commitment to sponsor the CBCF Annual Legislative Weekend's fashion shows. ${ }^{123}$ Although the congressmen said they "[looked] forward to the opportunity to reciprocate in the very near future", their request was initially denied because PM marketing executives felt that attendees at the CBCF fashion shows "[did] not represent a target franchise for product promotion or publicity". ${ }^{124}$ However, because the industry was then fighting the excise tax battles, CBC support was strategically important. Corporate office pressure led PM to sponsor the CBCF events after all, for reasons revealed in a memo from Stanley Scott, vice president of public affairs, to Ellen Merlo, vice president of marketing services.
". . .I received correspondence from our . . .Federal Relations office in Washington urging me to contact four members of the Congressional Black Caucus on the critical issue of proposed increased excise taxes . . In view of this direct request from the Black Caucus leadership and the ongoing Philip Morris political support of this constituency . . .I urge reconsideration of your decision in this [sponsorship] matter." 46

The CBC solicited Philip Morris to financially support the fashion shows, but did not want cigarette brand support publicised. ${ }^{125} 126$ Philip Morris, expecting visibility and an opportunity to promote its Virginia Slims brand, ${ }^{127}$ instead met resistance:

" . . the program cover for the .. fashion show will now not include "presented by Virginia Slims" . . and [with] the Caucus unhappiness with being associated with a cigarette brand, we have lost all Virginia Slims presence at the event." 125

RJR was also experiencing resistance from Johnson Publications, publisher of Ebony and Jet magazines, regarding promotion of MORE cigarettes at the Ebony fashion shows. Due to public pressure, Ebony suspended its affiliation with the cigarette. ${ }^{3}$ A memo from RJR's EM Blackmer, vice president of marketing operations, to Benjamin Ruffin noted:

" . . the MORE Brand has been involved with the Ebony Fashion Fair for a number of years. . We have been frustrated by our attempts to develop a stronger association between the MORE Brand and the Fashion Fair event. Johnson has responded that they do not wish to give the impression that RJR is "sponsoring" the activity." ${ }^{\prime 28}$

\section{Defusing opposition from within African American communities}

Courting leaders helped the industry defuse potential opposition. A 1982 internal industry study suggested that African American leaders were least likely to support actions against companies "having good records of black-related employment practices and support of black community activities" ${ }^{30}$ In the late 1980s, as black tobacco control activists were becoming more vocal, the industry used black leaders to counter their efforts.

For example, when the industry was criticised for advertising targeting minorities, it fought back with Benjamin Hooks, executive director of the NAACP. In 1989, Hooks (listed as a candidate for the industry's speaker program $^{96}$ ) publicly defended tobacco companies against the charges of targeting. In an article "What about individual choice?", Hooks noted increased critical attention to tobacco advertising practices. He wrote:

"Implicit in this is the premise that Blacks are so naive they will be persuaded to smoke by a billboard or an ad . . This is an insidious form of paternalism. Blacks, like the rest of the populace, can make the choice of whether to smoke or not." 129

In January 1990, RJR attempted to test market in Philadelphia a new mentholated cigarette called Uptown. ${ }^{130}$ Convinced that this represented targeting of African Americans, ${ }^{4131}$ enraged community leaders organised opposition. ${ }^{132}{ }^{133}$ Federal Health and Human Services Secretary Louis W Sullivan publicly denounced RJR. ${ }^{134}$ In an unsigned RJR response to Dr Sullivan on 18 January 1990, the industry again allied itself with Hooks:

"I received your letter asking us to cancel our plans to test market . . Uptown . . .l am particularly distressed by the 
paternalistic tone ... We do not agree with the implication that black consumers are less capable than others of making the personal decision of whether or not to smoke .. We share this opinion with Dr. Benjamin L. Hooks, executive director of the NAACP." ${ }^{135}$

On 19 January 1990, the NAACP released its public statement on the Uptown marketing campaign. Hooks, in a carefully worded statement, said:

"As an organization deeply rooted in the black community, we at the NAACP are aware that the decision of the R.J. Reynolds Company to single out this community as the target of its marketing efforts on behalf of . . ."Uptown", is being broadly perceived in a negative manner . . .the NAACP will seek a meeting to express our concerns with company officials. " ${ }^{136}$

Hooks wrote privately to James Johnston, RJR president/ CEO, requesting a meeting. Hooks wrote, " . . great concern exists about the apparent "targeting" of cigarette marketing to the black community . . .I am requesting an opportunity to meet with you ...for a discussion of this matter, which is of great importance to both of us." ${ }^{137}$ Although Hooks' letter emphasised the matter's "importance," he did not publicly oppose Uptown. In fact, in a Time Magazine interview he was implicitly critical of "Uptown opponents", arguing that they had adopted "the rationale that blacks are not capable of making their own free choices". ${ }^{132}$ An RJR memo written before Uptown's introduction shows that the industry considered Hooks a reliable ally.

"Should protest from the black community . . .reach a point where broad national response is neces-

sary ... Ask Ben Hooks and others within the black community to host lunches, breakfasts, or other events with their constituents." ${ }^{138}$

On 19 January, due to public pressure, RJR cancelled Uptown. ${ }^{139} 140$ Hooks, frequently quoted by other industry spokespersons, ${ }^{141-145}$ was later lauded by RJR as a "friend and supporter who was one of few individuals to say anything positive on [RJR's] behalf in the wake of Uptown."'146 Hazel Dukes, president of the New York state conference of NAACP branches, was another NAACP tobacco industry ally. ${ }^{147}{ }^{148}$ As a member of the Committee for Common Courtesy, an industry front group, ${ }^{149}$ she actively promoted tobacco interests ${ }^{21}$ by opposing clean air policies in New York City. ${ }^{150-154}$ The industry also used its alliances to counter critics more generally. Accusing industry opponents of racism was suggested as an effective industry strategy in an RJR document from 1990 that discusses a meeting held to discuss possible coalitions between the cigarette and beer industries. The document suggests themes for a campaign to counter industry critics, including "our critics are elitist and racist". ${ }^{155}$

\section{DISCUSSION}

Others have previously described the tobacco industry's influence in the African American community, noting that tobacco money, especially in earlier periods, supported organisations that might otherwise have failed for lack of funding. ${ }^{3156}$ The full extent of the tobacco industry's financial presence remains unseen ${ }^{157}$ and is probably underestimated here, since given the voluminous nature of the document collections, we cannot assure that we have examined all potentially relevant documents. However, the internal industry documents now allow us to understand better the underlying reasons why some of this support was provided.

What this study illustrates is that the tobacco industry has for decades meticulously cultivated relationships with virtually every leader and leadership group within the African

\section{What this paper adds}

Among all racial and ethnic groups in the USA, African Americans bear the greatest burden from tobacco related disease. The tobacco industry has been highly influential in the African American community for decades, providing funding and other resources to community leaders and emphasising publicly its support for civil rights causes and groups, while ignoring the negative health effects of its products on those it claims to support. However, the industry's private business reasons for providing such support were hitherto unknown.

This analysis of previously secret internal tobacco industry documents provides for the first time a clearer picture of the tobacco industry's practices and purposes in establishing strong relationships with the African American community. The industry established relationships with virtually every African American leader and organisation for three specific business reasons: to increase African American tobacco use, to use African Americans as a frontline force to defend industry policy positions, and to defuse tobacco control efforts. This paper provides detailed documentation of these purposes. As the tobacco industry expands globally, public health advocates should anticipate similar industry efforts to exploit the vulnerabilities of other marginalised groups.

American community, and that this effort was expended not merely out of generosity, but for at least three specific business reasons: to develop and increase tobacco use among African Americans; to use African Americans as a frontline force to advance and defend industry policy positions; and to defuse or obstruct tobacco control efforts arising from both within and outside the community.

The African American community, like other marginalised communities recognised as strategically important to the industry, has in some instances sought out and benefited from tobacco industry financial support estimated at \$25 million yearly. ${ }^{157}$ Some might argue that the relationships have been mutually instrumental, since African American groups received needed support in exchange for their backing of protobacco legislation or their silence on health issues. However, given the now widely acknowledged, disproportionately destructive impact of tobacco use on African Americans, the price extracted from the community in pain, suffering, sickness, early death, and loss of community elders may outweigh financial gains. At \$25 million a year, the 45000 African Americans who die annually from preventable tobacco related diseases are figuratively traded for a mere \$555 apiece.

The tobacco industry regards African Americans as a group with particular historic, social, and economic vulnerabilities, ${ }^{158}$ and it exploits these vulnerabilities by attempting to portray addiction to cigarettes as a civil right and a free choice. By providing monetary and social recognition, the industry also suggests a picture of inclusion and friendship. However, it chooses to ignore the devastating impact of its products on the very group of people it claims to support.

The tobacco industry's relationships with the African American community also suggest patterns of activity that may be repeated as the industry expands its global reach. It can be anticipated that where racial or ethnic divisions create groups that are marginalised, yet constitute potential markets, opportunities for well publicised corporate philanthropy, or emerging political power blocs, the tobacco industry may attempt to exploit groups' marginalisation by providing resources and recognition. In turn, such groups may develop economic dependence on tobacco funding and reluctance to challenge industry practices. 


\section{Conclusion}

The pervasive presence of the tobacco industry among all spheres of leadership in the African American community suggests that special public health challenges remain. The first steps, calling attention from within the community to the harms caused by tobacco and questioning the continued normalisation of tobacco use implied in accepting tobacco promotions and money, have already been undertaken. The next steps are harder, because they involve overtly confronting the economic chokehold developed by the industry, publicising the harms caused by continuing to permit it, holding leaders accountable, and considering alternative sources of funds. Only the community itself can decide whether certain leaders, organisations and/or activities are truly worth the hidden price the community pays to sustain them with tobacco industry dollars.

\section{ACKNOWLEDGEMENTS}

This work was supported by California Tobacco Related Disease Research Program (9RT-0095) and National Cancer Institute Grant 1R01CA87472-01. For providing comments on earlier drafts we thank the Writing Seminar at the Institute for Health Policy Studies, Lisa Bero, Margaret Daniel, Elizabeth Smith, and Ainye Long. We also thank our advisory panel members: Brenda Bell Caffee, Charyn Sutton, and Joseph Therrien.

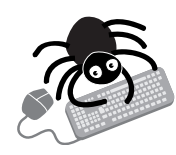

To see additional data, view this article on the Tobacco Control websitewww.tobaccocontrol.com

\section{Authors' affiliations}

V B Yerger, *R E Malone, Department of Social and Behavioral Sciences, School of Nursing, and Center for Tobacco Control Research \& Education, University of California, San Francisco, California, USA

*Also Institute for Health Policy Studies, University of California

\section{REFERENCES}

1 US Department of Health and Human Services. Tobacco use among U.S. racial/ethnic minority groups: African Americans, American Indians and Alaska Natives, Asian Americans and Pacific Islanders, Hispanics. A report of the Surgeon General, 1998. Atlanta, Georgia: Centers for Disease Control and Prevention, Office on Smoking and Health, 1998. (US Government Printing Office Publication No S/N 017-001-00527-4.)

2 Cooper R, Simmons B. Cigarette smoking and ill health among black Americans. July 1985. Access date: 22 February 2002. Bates No. TIMN0181460-1465. URL: http://legacy.library.ucsf.edu/tid/bli82fOO

3 Robinson RG, Pertschuk M, Sutton C. Smoking and African Americans: spotlighting the effects of smoking and tobacco promotion in the African American community. In: Samuels SE, Smith MD, eds. Improving the health of the poor: strategies for prevention. Menlo Park, California: Henry J Kaiser Family Foundation, 1992:122-81.

4 Headen SW, Robinson RG. Tobacco: from slavery to addiction. In: Braithwaite RL, Taylor SE, eds. Health issues in the black community. San Francisco: Jossey-Bass Inc, 2001:347-83.

5 Emont SL, Dorrell SM, Bishop K, et al. The burden of smoking-attributable mortality among African Americans - Indiana, 1990. Addictive Behaviors 1995;20:563-9.

6 Centers for Disease Control and Prevention. Fact sheet: African Americans and tobacco. US Department of Health and Human Services; 1998, updated July 2000

7 Robinson RG, Barry M, Bloch M, et al. Report of the Tobacco Policy Research Group on marketing and promotions targeted at African Americans, Latinos, and women. Tobacco Control 1992;1(suppl):S2430.

8 Sutton C, The Onyx Group. The end of tobacco billboards: An assessment. July 2000.

9 Library and Center for Knowledge Management, University of California, San Francisco website. URL: http://legacy.library.ucsf.edu

10 Balbach E, Gasior R, Barbeau E. Tobacco industry documents: Comparing the Minnesota Depository and internet access. Tobacco Control 2002; 11:68-72.

11 Malone R, Balbach E. Tobacco industry documents: treasure trove or quagmire? Tobacco Control 2000;9:334-8.

12 Centers for Disease Control and Prevention. CDC tobacco industry documents website. URL: http//www.cdc.gov/tobacco/industrydocs/ index.htm

13 Philip Morris Company website. URL: http://www.pmdocs.com

14 RJ Reynolds Tobacco Company website. URL: http:// www.rirtdocs.com
15 Brown and Williamson Company website. URL: http:// www.bw.aalatg.com

16 Lorillard Tobacco Company website. URL: http:// www.lorillarddocs.com

17 The Tobacco Institute website. URL: http://www.tobaccoinstitute.com

18 ISI ResearchSoft. Thomson Corporation. Philadelphia. URL: www.endnote.com

19 Northrup H, Ash R. The racial policies of American industry: The Negro in the tobacco industry. Philadelphia University of Pennsylvania, Wharton School of Finance and Commerce, Department of Industry, Industrial Research Unit, 1970. Report No. 13

20 Brown GF. Philip Morris' Human Relations Program sets pace for industry. Philip Morris Companies Inc. 17 October 1953. Access date: 12 December 2001. Bates No. 2041942541-2544. URL: http://legacy.library.ucsf.edu/tid/nqe45d00

21 Kluger R. Ashes to ashes: America's hundred-year cigarette war, the public health, and the unabashed triumph of Philip Morris. New York: Vintage Books, 1996

22 Philip Morris. [Philip Morris' involvement in the black community, draft] 24 December 1987. Access date: 20 February 2001. Bates No. 2021 199107-91 19. URL: http://legacy.library.ucsf.edu/tid/kyc42d00

23 Rowe I. Izzy Rowe's Note Book: The period which was. New Pittsburg Courier. 16 January 1965. Volume 6, number 1, Page 17: New York City.

24 Philip Morris News. [Herb Wright's 30th Anniversary with Philip Morris]. Philip Morris. 1975. Access date: 1 February 2002. Bates No. TIMSO0 11 188-1 195. URL: http://legacy.library.ucsf.edu/tid/Itx22fO0

25 Hughes I. [Letter to Tobacco Institute's President Sam Chilcote]. Brown \& Williamson. 16 April 1984. Access date: 23 July 2001. Bates No. 690137987. URL: http://legacy.library.ucsf.edu/tid/dlr93f00

26 Dollars \& Sense Magazine. Tobacco \& black Americans, Part II: The industry's view. June/July, 1990. Bates No. 515993397-3402. URL: http://legacy.library.ucsf.edu/tid/emb92d00

27 Philip Morris Companies Inc. [Biography of Hugh Cullman]. 5 February 1990. Access date: 11 December 2001. Bates No. 2048378457-8458. URL: http://legacy.library.ucsf.edu/tid/agp 16 e00

28 Editorial. Cigarette companies go to college. New York State Journal of Medicine. July 1985. Access date: 22 February 2002. Bates No. TIMN0181460-1465. URL: http://legacy.library.ucsf.edu/tid/bli82f00

29 Philip Morris USA. [Description of the Public Affairs/Government Relations]. 16 December 1981. Access date: 27 March 2001. Bates No. 2024077433-7448. URL: http://legacy.library.ucsf.edu/tid/ xvy36e00

30 Clark, Phipps, Clark \& Harris Inc. A study of the attitudes of black leaders. Prepared for Philip Morris. 13 December 1982. Access date: 20 February 2001. Bates No. 2040271913-1967. URL: http://legacy.library.ucsf.edu/tid/zcc42d00

31 Bateman M. [Memo to the Senior Vice President of Corporate Marketing]. Brown \& Williamson. 4 May 1983. Access date: 23 July 2001. Bates No. 675207397-7400. URL: http:// legacy.library.ucsf.edu/tid/jvi73f00

32 JRH Marketing Services Inc. Summary report of qualitative research on corporate image advertising among African American opinion leaders. Prepared for RJ Reynolds Nabisco. May 1990. Access date: 25 January 2002. Bates No. 507712740-2759. URL: http:// legacy.library.ucsf.edu/tid/dux 14 d00

33 Knox G. [Afro-Americans and the evolution of a living constitution]. Philip Morris Companies Inc. 3 May 1989. Access date: 23 September 2001. Bates No. 2023277409-7410. URL: http://legacy.library.ucsf.edu/tid/ nsw36e00

34 RJ Reynolds. [Black market corporate creative strategy]. 18 January 1990. Access date: 10 January 2002. Bates No. 507234461. URL: http://legacy.library.ucsf.edu/tid/qbk54d00

35 Ruffin B. [Public-service billboard ads]. RJ Reynolds Tobacco Co. 16 September 1991. Access date: 20 August 2001. Bates No. 507763484-3485. URL: http://legacy.library.ucsf.edu/tid/afs 14d00

36 Roberts A. 1988 Constituent organization annual report. Philip Morris 5 January 1989. Access date: 25 January 2002. Bates No. 2023263670-3688. URL: http://legacy.library.ucsf.edu/tid/nfi46e00

37 RJ Reynolds Nabisco. Current special public relations programs. 1990. Access date: July 2001. Bates No. 512722734-2745. URL: http://legacy.library.ucsf.edu/tid/qge33d00

38 Reed W. Congressional Black Caucus week. The Sun Reporter. 16 September 1992. Volume 48, number 38, page 1 Lifestyles.

39 Smith G. [September report on Public Affairs]. Philip Morris Companies Inc. 11 October 1990. Access date: 7 February 2001. Bates No. 2047572404-2409. URL: http://legacy.library.ucsf.edu/tid/uqb72e00

40 Wallace S, Hughes I. [Fair Share Pact]. Brown \& Williamson. 11 July 1983. Access date: 18 July 2001. Bates No. 670221966-1973. URL: http://legacy.library.ucsf.edu/tid/kfcl $4 \mathrm{fOO}$

41 Bateman M. [Total minority marketing plan]. Brown and Williamson. 7 September 1984. Access date: 28 February 2002. Bates No. 531000141-0144. URL: http://legacy.library.ucsf.edu/tid/eph40f00

42 Bass M. [Letter to NAACP executive director]. RJ Reynolds Nabisco. 24 February 1987. Access date: July 2001. Bates No. 505480893. URL: http://legacy.library.ucsf.edu/tid/ywr15d00

43 Givel M, Glantz S. Tobacco lobby political influence on US state legislatures in the 1990s. Tobacco Control 2001;10:124-34.

44 Still LA. Black Caucus reshuffles staff. Portland Skanner Newspaper. 25 December 1985. Volume 11, number 12, page 5

45 Philip Morris. [Philip Morris' involvement in the black community]. Philip Morris. 1 April 1988. Access date: 20 February 2001. Bates No. 2023647454-7470. URL: http://legacy.library.ucsf.edu/tid/mqc42d00 
46 Scott S. [Congressional Black Caucus Foundation fashion shows]. Philip Morris Companies Inc. 9 June 1987. Access date: 13 March 2001. Bates No. 204900443 1-4432. URL: http://legacy.library.ucsf.edu/tid/ dew83e00

47 Day One Program. [Transcript of Rangel interview]. ABC-TV. 14 July 1994. Access date: 23 September 2001. Bates No. 2045999098-9102. URL: http://legacy.library.ucsf.edu/tid/iqg65e00

48 Smith G. [August report on Public Affairs]. Philip Morris Companies Inc. 7 September 1990. Access date: 22 January 2001. Bates No. 2021 198897-8900. URL: http://legacy.library.ucsf.edu/tid/wjl46e00

49 RJ Reynolds. [Minority Affairs Publicity Program]. 1983. Access date: 4 March 2002. Bates No. 505478647-8675. URL: http:// legacy. library.ucsf.edu/tid/xsr $15 \mathrm{~d} 00$

50 Black F. [Letter to Benjamin Ruffin, RJR's Corporate Affairs VP]. National Newspaper Publishers Association. 21 September 1994. Access date: 23 September 2001. Bates No. 518284163 -4163. URL: http://www.rirtdocs.com/rirtdocs/image_viewer.dms? $\mathrm{PS}=1$ \&DOC_RANGE $=518284163+-4163$ \&SEARCH $=895$ \&CAMEFROM=1

51 Curtis C. Trip report - National Urban League's Black Executive Exchange Program. RJ Reynolds Tobacco Co. 5 July 1990. Access date: 23 September 2001. Bates No. 508106605-6606. URL: http://legacy.library.ucsf.edu/tid/php04d00

52 Tobacco Institute. [Report of activities]. 31 December 1982. Access date: 20 September 2001. Bates No. 2015018182-8214. URL: http://legacy.library.ucsf.edu/tid/voi23e00

53 Hennes B. Weekly activity report. RJ Reynolds Tobacco Co. 24 July 1991. Access date: 23 September 2001. Bates No. 507697712 -7721. URL: http://www.rirtdocs.com/rirtdocs/image viewer.dms? $\mathrm{PS}=1$ \&DOC_RANGE $=507697712+-7721$ \&SEARCH $=899$ \&CAMEFROM=1

54 F Cynthia, F Ron. 2nd quarter status report. RJ Reynolds Tobacco Co. 25 July 1991. Access date: 23 September 2001. Bates No. 507756387-6395. URL: http://legacy.library.ucsf.edu/tid/drs 14d00

55 Philip Morris. [List of sponsored black and Hispanic organizations, part A]. 1989. Access date: 25 January 2002. Bates No. 2023263672-3688. URL: http://legacy.library.ucsf.edu/tid/fyo02a00

56 Jha $\mathbf{P}$, Chaloupka $\mathrm{F}$. The economics of global tobacco control. BM 2000;321:358-61.

57 The World Bank. Curbing the epidemic: governments and the economics of tobacco control. Washington DC: The International Bank for Reconstruction and Development; 1999

58 Centers for Disease Control and Prevention. Response to increases in cigarette prices by race/ethnicity, income, and age groups - United States, 1976-1993. MMWR Morb Mortal Wkly Rep 1998;47:605-9.

59 Warner KE. The cigarette advertising broadcast ban and magazine coverage of smoking and health. Journal of Public Health Policy 1989:32-42.

60 Johnston M. Handling an excise tax increase. Philip Morris USA. 3 September 1987. Access date: 23 July 2001. Bates No. 2022216179-6180. URL: http://legacy library.ucsf.edu/tid/uvx71fOO

61 Chilcote S. Comments made at the annual meeting. Tobacco Institute. 13 December 1984. Bates No. TIMN0061487-1502. URL: http://legacy.library.ucsf.edu/tid/xaa03f00

62 Corporate Affairs Department. Strategy and tactics for combating smoking issues. Philip Morris USA. March 1985. Access date: 10 September 2001. Bates No. 2021502332-2347. URL: http://legacy.library.ucsf.edu/tid/xrx36e00

63 Chilcote S. [Memo to Executive Committee]. Tobacco Institute. 14 May 1990. Access date: 14 January 2002. Bates No. $2025862213-2218$. URL: http://legacy.library.ucsf.edu/tid/dkl14e00

64 Raspberry W. Budgeting good sense. The Washington Post. 23 March 1981. Section A, page 15.

65 Tolchin M. Two budgets proposed by House liberals suffer solid defeat. The New York Times. 7 May 1981. Section A, page 1.

66 Tobacco Institute. Infolog Newsletter. 6 May 1981. Access date: 12 February 2001. Bates No. 2026266031-6033. URL: http://legacy.library.ucsf.edu/tid/apu25e00

67 Tobacco Institute. Newsletter. 2 June 1981. Access date: 21 February 2002. Bates No. 89004270-4275. URL: http://legacy.library.ucsf.edu/ $\mathrm{tid} / \mathrm{rky} 80 \mathrm{eO0}$

68 UPI. Blacks in Congress offer alternative budget plan. The New York Times. 19 March 1981. Section B, page 13.

69 Merin C. The tax bill. Tobacco Institute. 5 June 1984. Access date: 2 April 2001. Bates No. 2024263500-3502. URL: http:// legacy.library.ucsf.edu/tid/qyi85e00

70 Chilcote S. [Memo to the Executive Committee]. Tobacco Institute. 21 June 1985. Access date: 23 July 2001. Bates No. $516012237-2238$. URL: http://legacy.library.ucsf.edu/tid/xcq24f00

71 Chilcote S. [Memo to Executive Committee]. Tobacco Institute. 27 June 1985. Access date: 6 August 2001. Bates No. 85694277-4279. URL: http://legacy.library.ucsf.edu/tid/fci3 1 e00

72 Miller A. Jimmy Hargrove of the National Black Police Association. Philip Morris USA. 23 April 1985. Access date: 10 September 2001. Bates No. 2025851385. URL: http://legacy.library.ucsf.edu/tid/zcn $14 \mathrm{e} 00$

73 Hargrove J. Anti-smoking laws discriminate against blacks and minorities. Philip Morris Companies Inc. June 1985. Access date: 10 September 2001. Bates No. 2026240976. URL: http:// legacy.library.ucsf.edu/tid/vvd8 1 f00

74 Anon. RSVPs for Vann fundraiser. 28 August 1985. Access date: 10 September 2001. Bates No. 2024263371-3372. URL http://legacy.library.ucsf.edu/tid/iuq $14 \mathrm{e} 00$

75 Roberts A. Jimmy Hargrove briefing re: NYC council meeting. Philip Morris USA. 5 April 1985. Access date: 10 September 2001. Bates No. 2025851384. URL: http://legacy.library.ucsf.edu/tid/ycn 14 e00
76 Philip Morris. [List of witnesses speaking against smoking restriction]. 14 January 1986. Access date: 10 September 2001. Bates No. 2024272162. URL: http://legacy.library.ucsf.edu/tid/ohp 14e00

77 Hargrove J. [Testimony before the New York Public Health Council] National Black Police Association. 3 November 1986. Access date: 10 September 2001. Bates No. 2024274534-4537. URL: http://legacy.library.ucsf.edu/tid/zng35e00

78 Roberts A. New York State Public Health Council. Philip Morris USA. 4 November 1986. Access date: 10 September 2001. Bates No. 2024274533. URL: http://legacy.library.ucsf.edu/tid/yng35e00

79 Anon. Jackson blasts cigarette tax. Portland Skanner. 25 September 1985. Volume 10, number 49 , page 4

80 Philip Morris Inc. Mobilization manual. Brown and Williamson. 1976. Access date: 22 May 2002. Bates No. 680277776-7812. URL: http://legacy.library.ucsf.edu/tid/ifm04f00

81 Kloepfer W. Tobacco College curriculum. Tobacco Institute. 7 July 1983. Access date: 22 May 2002. Bates No. 2023023440. URL: http://legacy.library.ucsf.edu/tid/dzw36e00

82 Bloom M. [Memo to RJR Vice President E.A. Vassallo]. Tobacco Merchants Association of US. 3 August 1973. Access date: 22 May 2002. Bates No. 500367620. URL: http://legacy.library.ucsf.edu/tid/ lqv79d00

83 Chilcote S. [Memo to Executive Committee]. Tobacco Institute. 26 June 1987. Access date: 11 April 2001. Bates No. 2025855801-5803. URL: http://legacy.library.ucsf.edu/tid/jhm $14 \mathrm{e} 00$

84 Chilcote S. [Memo to Executive Committee]. Tobacco Institute. 2 July 1987. Access date: 10 September 2001. Bates No. $88116601-6605$. URL: http://legacy.library.ucsf.edu/tid/kpc90e00

85 Dymally M. [Task Force Report]. Congressional Black Caucus. July 1987. Access date: 16 April 2001. Bates No. TITX0034333-4356. URL: http://legacy.library.ucsf.edu/tid/jww32fOO

86 Tobacco Institute. Phil-Pac contributions to 1984 campaigns (1983-84 election cycle). 11 December 1984. Access date: 22 February 2002. Bates No. 20254181 18-8124. URL: http://legacy.library.ucsf.edu/tid/ cip02a00

87 Tobacco Institute. Honoraria Program, May. June 1987. Access date: 22 February 2002. Bates No. 2025856174. URL: http:// legacy.library.ucsf.edu/tid/nar85e00

88 Tobacco Institute. Honoraria Program, July. 9 August 1989. Access date: 22 February 2002. Bates No. 2025848491. URL: http://legacy.library.ucsf.edu/tid/fxq24e00

89 Tobacco Institute. TIPAC contributions 1989. 29 November 1989. Access date: 18 March 2002. Bates No. 2025848470-8481. URL: http://legacy.library.ucsf.edu/tid/axq24e00

90 Dymally M. [Testimony at congressional hearing]. Congressional Black Caucus. 15 July 1987. Access date: July 2001. Bates No. $88116433-6434$. URL: http://legacy.library.ucsf.edu/tid/poc90e00

91 Chilcote S. [Memo to Executive Committee]. Tobacco Institute. 6 Augus 1987. Access date: 8 October 2001. Bates No. 88122986-2987. URL: http://legacy.library.ucsf.edu/tid/xic $90 \mathrm{eO0}$

92 Tobacco Institute. Executive Summary. 11 September 1987. Access date: 10 September 2001. Bates No. 93440464-0465. URL: http://legacy.library.ucsf.edu/tid/Ims60e00

93 Sparber P, Ross J, Stuntz S, et al. [Public Affairs progress report]. Tobacco Institute. 28 January 1988. Access date: 17 April 2001. Bates No. TIDN0018389-8431. URL: http://legacy.library.ucsf.edu/tid/ gyh91f00

94 California's seven freshmen in Congress featured. Los Angeles Times. 23 November 1981. Part I, page 18.

95 Schoonmaker D, Hrycaj C. Tax hearing readiness. Tobacco Institute. 1989. Access date: 23 September 2001. Bates No. $92761030-1042$ URL: http://legacy.library.ucsf.edu/tid/nci70e00

96 Philip Morris. [Industry spokespersons]. 1990. Access date: 25 July 2001. Bates No. 92758925-8928. URL: http://legacy.library.ucsf.edu/ $\mathrm{tid} /$ onh70e00

97 Tobacco Institute. Smokers already pay more than their fair share. 18 November 1993. Access date: 10 September 2001. Bates No. 89735140 . URL: http://legacy.library.ucsf.edu/tid/gve0 le00

98 Lee D. [Statement before the Ways \& Means Committee]. Tobacco Institute. 18 November 1993. Access date: 20 September 2001. Bates No. 2046926765-6771. URL: http://legacy.library.ucsf.edu/tid/ ofn $65 \mathrm{e} 00$

99 Philip Morris. [List of Congress members and amount of PHIL-PAC contribution]. 7 June 1989. Access date: 15 April 2002. Bates No. 2021502080-2082. URL: http://legacy.library.ucsf.edu/tid/aqs24e00

100 Tobacco Institute Political Action Committee. TIPAC Legislative Activity and Issues. Tobacco Institute. 31 December 1989. Access date: 2 April 2001. Bates No. 2024269707-9799. URL: http:// legacy.library.ucsf.edu/tid/ydp02a00

101 Tobacco Institute. TIPAC contributions 1993. 2 April 1993. Access date: 18 March 2002. Bates No. 2023344761-4763. URL: http://legacy.library.ucsf.edu/tid/vfp24e00

102 Tobacco Institute. Federal relations report. July 1982. Access date: 3 July 2001. Bates No. TIMN0145301-5370. URL: http:// legacy.library.ucsf.edu/tid/mib92f00

103 Philip Morris, RJ Reynolds. [Joint tobacco task force]. January 1993. Access date: 23 April 2001. Bates No. 2048583231-3254. URL: http://legacy.library.ucsf.edu/tid/gmt81 f00

104 Morrow R, Glasser. [Rostenkowski's pending departure]. Smith Barney Shearson. 27 May 1994. Access date: 18 April 2001. Bates No. 2024336200. URL: http://legacy.library.ucsf.edu/tid/omm09e00

105 Glantz SA, Balbach ED. Tobacco wars. Berkeley, California: University of California Press; 2000. 
106 Promotions Resources Inc. City of Chicago black sampling opportunities. RJ Reynolds. 23 January 1984. Bates No. 5038941 84-4226. URL: http://legacy.library.ucsf.edu/tid/xxt75d00

107 Tobacco Institute. Executive Summary. 13 November 1987. Access date: 1 March 2002. Bates No. 93440445-0446. URL: http://legacy.library.ucsf.edu/tid/cms60e00

108 Tobacco Institute. Executive Summary. 18 December 1987. Access date: 1 March 2002. Bates No. 93440435-0436. URL: http://legacy.library.ucsf.edu/tid/xls60e00

109 Tobacco Institute. Executive Summary. 17 March 1989. Access date: March 2002. Bates No. 92746275-6276. URL: http:// legacy.library.ucsf.edu/tid/ori70e00

110 Osmon H. [Council of Black Churches]. RJ Reynolds. 12 February 1991. Access date: 1 March 2002. Bates No. 507788852. URL: http://legacy.library.ucsf.edu/tid/vdp14d00

111 Lai J. [1994 contributions made to organizations]. Philip Morris Companies Inc. 30 January 1996. Access date: 20 February 2001 Bates No. 2046946005-6009. URL: http://legacy.library.ucsf.edu/tid/ eje58d00

112 Hudson R. [Memo regarding sampling activity at the NAACP convention]. Brown \& Williamson. 6 July 1979. Access date: July 2001 Bates No. 66006745 1-7452. URL: http://legacy.library.ucsf.edu/tid/ hrn89e00

113 Bass M. [Memo requesting cigarette samples]. RJ Reynolds Tobacco Co. 10 July 1984. Access date: 12 June 2001. Bates No. 505473272. URL: http://legacy.library.ucsf.edu/tid/aps 15d00

114 Ruffin B. [Memo requesting tobacco samples]. RJ Reynolds Nabisco. November 12, 1986. Access date: 23 September 2001. Bates No. 505476929. URL: http://legacy.library.ucsf.edu/tid/eas 15 d00

115 Mitchell K. [Request for cigarettes]. Lorillard. 20 October 1987. Access date: 23 September 2001. Bates No. 87789192. URL: http://legacy.library.ucsf.edu/tid/hch2 le00

116 Munden D. [Request for cigarettes]. Lorillard. 4 April 1989. Access date: 23 September 2001. Bates No. 87811199 . URL: http://legacy.library.ucsf.edu/tid//rk2 le00

117 Munden D. [Request for Newport samples]. Lorillard. 10 April 1990 Access date: 23 September 2001. Bates No. 87811154 . URL: http://legacy.library.ucsf.edu/tid/vpk2 l e00

118 Mitchell M. [Letter to CBCF executive director Frank Morris]. Congressional Black Caucus Foundation. 3 July 1984. Access date: 16 April 2001. Bates No. TIMN0245599-5600. URL: http:// legacy.library.ucsf.edu/tid/iwg72f00

119 Wharton G. [Congressional Black Caucus Foundation requests product samples]. Congressional Black Caucus Foundation. 8 June 1982. Access date: 3 May 2001. Bates No. 505472338. URL: http:// legacy.library.ucsf.edu/tid/rns $15 \mathrm{~d} 00$

120 Morris F. [Letter to RJ Reynolds's Norm Gaines]. Congressional Black Caucus Foundation. 6 July 1984. Access date: 16 April 2001. Bates No. TIMN0245598. URL: http://legacy.library.ucsf.edu/tid/hwg72f00

121 Glantz SA, Slade J, Bero LA, et al. The cigarette papers. Berkeley, California: University of California Press, 1996.

122 Anon. [Smoking not responsible for adverse health effects in Blacks]. Tobacco Institute. August 1984. Access date: 16 April 2001. Bates No. TIMN024560 1-5602. URL: http://legacy.library.ucsf.edu/tid/jwg72f00

123 Dixon J. [Congressional Black Caucus Foundation fashion shows]. Congressional Black Caucus. 22 May 1987. Access date: 7 February 2001. Bates No. 2049004435-4436. URL: http:// legacy.library.ucsf.edu/tid/mru95e00

124 Merlo E. [Congressional Black Caucus Foundation fashion shows]. Philip Morris USA. 5 June 1987. Access date: 13 March 2001. Bates No. 2049004433. URL: http://legacy.library.ucsf.edu/tid/eew83e00

125 Foster H. [Congressional Black Caucus Foundation fashion shows] Philip Morris USA. 26 August 1987. Access date: 13 March 2001 Bates No. 2044733037. URL: http://legacy.library.ucsf.edu/tid/ nge06e00

126 Merlo E. [Congressional Black Caucus Foundation fashion shows]. Philip Morris USA. 1 September 1987. Access date: 13 March 2001. Bates No. 2044733036. URL: http://legacy.library.ucsf.edu/tid/mge06e00

127 Dowling J. [Congressional Black Caucus Foundation fashion shows]. Philip Morris Companies Inc. 20 July 1987. Access date: 7 February 2001. Bates No. 2044733038-3039. URL: http:// legacy.library.ucsf.edu/tid/oge $06 \mathrm{eO}$

128 Blackmer EM. [Johnson Publications' Ebony Fashion Fair activities]. R Reynolds Tobacco Co. 14 December 1988. Access date: 20 August 2001. Bates No. 506780764-0765. URL: http:// legacy.library.ucsf.edu/tid/bbi44d00

129 Hooks B. What about individual choice? The Michigan Chronicle. 16 December 1989. Access date: July 2001. Bates No. 507776735 -6735. URL: http://www.rirtdocs.com/rirtdocs/image_viewer.dms? $P S=1 \& D O C \_R A N G E=507776735+-6735 \& S E A R C H=1668 \& C A M E F R O M=$

130 RJ Reynolds. External Affairs action plan: Project Uptown. 11 October 1989. Access date: 25 January 2002. Bates No. 507607083-7084. URL: http://legacy.library.ucsf.edu/tid/pih24d00

131 Hirsch DC. [Authorization request for Uptown introduction]. RJ Reynolds. 5 February 1990. Access date: 4 February 2002. Bates No. 508237937. URL: http://legacy.library.ucsf.edu/tid/lbc04d00

132 Doolittle DE. Free speech attacked. 1990. Access date: 23 September 2001. Bates No. $511473237-3238$. URL: http://www.rirtdocs.com/ rirtdocs/image_viewer.dms?

$\mathrm{PS}=1$ \&DOC RANGE $=511473237+-3238 \&$ SEARCH $=892 \&$ CAMEFROM $=1$

133 Brown J, Robinson RG, Allison Y, et al. [Test marketing of Uptown]. Coalition Against Uptown Cigarettes. 22 January 1990. Access date: 4
February 2002. Bates No. 507777144-7145. URL: http:// legacy.library.ucsf.edu/tid/efq $14 \mathrm{~d} 00$

134 Editorial Desk. Dr. Sullivan's unfiltered anger. New York Times. 21 January 1990.

135 Anon. [Response to Health and Human Services Secretary Sullivan]. R Reynolds. 18 January 1990. Access date: 23 September 2001. Bates No. 515197241 . URL: http://legacy.library.ucsf.edu/tid/awc03d00

136 Hooks B. [Statement on marketing campaign for "Uptown" cigarettes] NAACP. 19 January 1990. Access date: July 2001. Bates No. 507777183-7184. URL: http://www.rirtdocs.com/rirtdocs/ image_downloader.wmt?MODE $=P D F \& S E A R C H=8 \& R O W=1$ \&DOC_RANGE $=507777183+-7184 \&$ CAMEFROM=1 \& tab=search

137 Hooks B. [Letter to RJ Reynolds' president James Johnston]. NAACP. 19 January 1990. Access date: July 2001. Bates No. 507777182. URL: http://www.rirtdocs.com/rirtdocs/ image_downloader.wmt?MODE=PDF\&SEARCH=2\&ROW=1 \&DOC RANGE $=507777182+-7182 \&$ CAMEFROM $=1 \&$ tab $=$ search

138 Payne M. Revised Uptown planning. RJ Reynolds Nabisco. 12 January 1990. Access date: July 2001. Bates No. 507745368-5370. URL: http://www.rirtdocs.com/rirtdocs/ image downloader.wmt?MODE=PDF\&DOC_RANGE $=50774$ $5368 \% 20-5370 \&$ CAMEFROM=1

139 Slade J. [Uptown cancelled]. Commission on Smoking OR Health. 20 January 1990. Access date: 4 February 2002. Bates No. 507777146-7147. URL: http://legacy.library.ucsf.edu/tid/ffql 4d00

140 Schiffman J. After Uptown, are some niches out? Wall Street Journal. 22 January 1990. Access date: 4 February 2002. Bates No. TIMN0408859-8860. URL: http://legacy.library.ucsf.edu/tid/vma62f00

141 Lauria T. [Statement on behalf of Tobacco Institute]. Tobacco Institute. 1991. Access date: July 2001. Bates No. 93136290-6299. URL: http://legacy.library.ucsf.edu/tid/bzb60e00

142 Whitley CO. [Statement on behalf of Tobacco Institute]. Tobacco Institute. 27 February 1990. Access date: 23 September 2001. Bates No. TIMN203767-3783. URL: http://www.tobaccoinstitute.com/ getimg $\cdot$ asp?pgno $=0 \&$ start $=0 \& i f=a v t i d x \& b o o l=T I M N 0203767 \&$ docid= TIMN0203767/3783\&docnum $=1$ \&summary $=0$ \&sel $1=$

143 Larry King Live. Targeted advertising and other cigarette-related issues. Radio TV Reports Inc. 22 February 1990. Access date: 23 September 2001. Bates No. TIMN0125807-5824. URL: http:// legacy.library.ucsf.edu/tid/ehf92fOO

144 FNN-TV Focus. Cigarette advertising. Radio TV Reports Inc. 1 March 1990. Access date: 23 September 2001. Bates No. TIMN0125891-5901. URL: http://legacy.library.ucsf.edu/tid/khf92fOO

145 Association of National Advertisers. [Statement regarding "Tobacco Product Education and Health Protection Act of 1990"]. 20 February 1990. Access date: 24 July 2001. Bates No. 87705603-5610. URL: http://legacy.library.ucsf.edu/tid/rzm2 le00

146 RJ Reynolds Nabisco. [Community action corporate contributions]. 1993. Access date: 23 September 2001. Bates No. $511993955-3960$ URL: http://legacy.library.ucsf.edu/tid/iui43d00

147 Dawson B, Stuntz S. High-profile speakers. Tobacco Institute. 20 Apri 1990. Access date: July 2001. Bates No. 507775834-5837. URL: http://legacy.library.ucsf.edu/tid/nkq 14 d00

148 Tobacco Institute. Celebrity Spokesman Project. 1990. Access date: July 2001. Bates No. 92758920-8923. URL: http:// legacy.library.ucsf.edu/tid/mnh70e00

149 Committee for Common Courtesy. [Membership list]. May 1986 Access date: July 2001. Bates No. 85544127-4129. URL: http://legacy.library.ucsf.edu/tid/htu3 le00

150 Horowitz M. Committee for Common Courtesy. Howard J. Rubenstein Associates Inc. 15 May 1986. Access date: 23 September 2001. Bates No. 85544130-4132. URL: http://legacy.library.ucsf.edu/tid/itu3 le00

151 Anon. [Report on New York City smoking restriction proposal]. 1986. Access date: 25 July 2001. Bates No. 85648665-8667. URL: http://legacy.library.ucsf.edu/tid/eco3 1e00

152 Cherry J. New York City smoking proposal. Lorillard. 13 May 1986. Access date: July 2001. Bates No. 85544126 . URL: http:// legacy.library.ucsf.edu/tid/gtu3 1 e00

153 Buckley W. New York City report. Tobacco Institute. 21 May 1986 Access date: July 2001. Bates No. 85648640-8641. URL: http://legacy.library.ucsf.edu/tid/rbo3 le00

154 Howard J. Rubenstein Associates Inc. [Committee, not government intervention, to solve problems]. Committee for Common Courtesy. 1986 Access date: 25 July 2001. Bates No. 85648659-8661. URL: http://legacy.library.ucsf.edu/tid/bco3 le00

155 Osmon HE. Visit with Fleishman Hillard. RJ Reynolds Tobacco Company.20 December 1990. Bates No. 507786661-6668. URL: http://legacy.library.ucsf.edu/tid/hkp $14 \mathrm{~d} 00$

156 Blum A. Selling cigarettes: blue-collar, black target. Washington Post. 18 May 1986. Access date: April 1, 2002. Bates No. TIMN0362320-2321. URL: http://legacy.library.ucsf.edu/tid/chj52fOO

157 Gardiner P. Tobacco industry philanthropy in the black community. Burning Issues: Tobacco-Related Disease Research Program Newsletter July $2001 ; 4: 1-3$

158 RJ Reynolds. RJ Reynolds tobacco company new menthol cigarette introduction. 10 July 1990. Bates No. 507475465-5468. URL: http://www.rirtdocs.com/rirtdocs/ image_downloader.wmt? $M O D E=P D F \& S E A R C H=1 \& R O W=2$ $\& D O C \_R A N G E=507475465+-5468 \& C A M E F R O M=2 \&$ tab $=$ search 